\title{
Development Policies: Do They Really Fight Against Global Inequalities and Injustice? An Alternative and Critical Analysis
}

\section{Ander Arredondo Chopitea}

DOI: https://doi.org/10.22151/politikon.46.2 Ander Arredondo Chopitea, from Madrid (Spain), is a PhD student in Political Science at Complutense University of Madrid (UCM). He received his bachelor's degree in Political Science and Public Administration at UCM, a master's degree in International Development Cooperation (with a focus on Latin America) at Rey Juan Carlos University in Madrid (UJRC), and a master's degree in Public Policy at National Distance Education University (UNED). With several years of experience in the non-profit sector, he is currently the project manager at a Spanish NGO. His interests include development studies, publicpolicy, Marxism, decolonial studies and feminisms. E-mail: aaarredondo@,ucm.es

\begin{abstract}
This article examines development policies in the fight against inequalities and global justice using alternative and critical theories, establishing connections between the capitalist system and development policies as a social phenomenon inherent to it and analysing if these policies can address their abstract motivations and goals of justice and equality. The general findings of the article suggest that development policies contribute to the intensive and extensive expansion of capitalism as an instrument to impose and never confront Western economic interests. Moreover, the concepts of charity discourse and development imperative are introduced as the ideological foundations of development policies, which serve both to extend the idea that the struggle against inequalities and injustice generated by the capitalist system can and must be resolved within the framework of this system and as a device of social control and hegemony production from Western societies to the rest of the world.
\end{abstract}

\section{Keywords}

Capitalism; Critical Studies; Development; Development Policies; Ideology; Inequalities; Justice 


\section{Introduction}

This article examines development policies in the fight against inequalities and global justice from an alternative and critical perspective. If there is one area of policy that talks about global justice most prominently, it is development cooperation, a field which aims at diverse objectives such as ending hunger, achieving gender equality, and ending economic and social inequalities: in short, achieving "development". Historically, through these policies it has been claimed that these goals would be achieved in a relatively short period of time and, as argued in this article, without changing the economic structure.

In contrast to many studies focused on the quantitative measurement of the impact of these policies and those that place development policies as an isolated social phenomenon, barely related to capitalism and its economic and ideological interests, this article aims to establish connections between the capitalist system and development policies as a social phenomenon inherent in it.

Therefore, the article briefly examines whether the objectives and means of development policies are really based on abstract motivations such as "development" itself, fighting economic and social inequalities, discriminations and injustice at the global level, or are more influenced by clear and precise economic and ideological interests that clash with those motivations.

To this end, the article structures the analysis in three sections: the first one is devoted to a brief review of the literature regarding international aid, identifying the main problems and gaps. The second and principal section seeks to reposition the debate on development policies as a social phenomenon inherent to the capitalist system, with the aim of determining whether development policies really fight against global inequalities and injustice through examining the economic and ideological dimensions of these policies. The third section will focus on analysing alternative paths with respect to development policies under the idea of global justice. Finally, conclusions and paths for future research will be offered.

Critical and alternative theoretical perspectives, specifically Marxism and decolonial theories, will guide this article. As this is a conceptual and explanatory analysis of development policies, Marxism will help to frame the discussion, offering theoretical and methodological tools to examine the economic components on which these policies are based and their function in global capitalism as well as to analyse the dominant ideology behind the development discourse. Decolonial theories will provide valuable insights on the role of Western development policies through the notions of coloniality of power, knowledge and being, through the imposition of ideas, institutions and practices absolutely unconnected to the reality and the background of 
impoverished countries, with the objective of maintaining a (neo)colonial control through these policies.

In this sense, the methodology used for this article relies on the use of the Marxist approach on dialectic, which, together with the theoretical framework provided by Marxism and decolonial studies, will enable the alternative and critical analysis of development policies. The use of Marxist dialectic as a methodological guide is particularly useful for the conceptual analysis of these policies as it provides methodological tools to frame the subject of study within the framework of a specific social totality by identifying and tracking the connections with other economic, political and ideological phenomena that influence development policies, and, at the same time, are also influenced by them (Kosík 1967). These links are set as a result of the analysis, which means that any apriorism must be avoided (Marx 1975a, 19-20) when it comes to determining other causes for why development policies exist and how they function in the framework of the capitalist system.

For this purpose, primary and secondary sources are used. As for primary sources, original mainstream literature on development policies and studies of the key theoreticians of Marxism and of the decolonial studies are employed to provide the theoretical grounds for the analysis as well as for the identification of the links between these policies and the functioning logic of the capitalist system. As for secondary sources, studies in the field of development and statistical sources of the main organisations related to development policies are analysed.

The general conclusions of the article suggest that development policies are not so much about the urgent need to fight against injustice and inequalities. On the economic level, they contribute to the expansion of capitalism by complementing - and never confronting - the economic policies of Western countries. Meanwhile, on the ideological level, development policies in general act as a device for social control and hegemony production by which Western societies seek to dominate the rest of the world.

\section{Current debate: Abstractions, lack of analysis, hackneyed roads and sterile evidence}

\section{Abstractions and lack of analysis of the causes that generate global inequalities and injustice}

Nearly every decade since the Second World War, a new paradigm on development has been established (Escobar 2005, 18). Each change has blamed the previous paradigm for the ineffectiveness of these policies, for the unsolved vices and abiding problems, and consequently new instruments have been suggested and some sectors have been strengthened at the expense 
of others. These policy changes are always accompanied by a modulation in the official discourse of development, in accordance with continuous variations in the dominant ideology.

These policy reversals have been made through two channels: academic discussion and empirical evidence about the results of development policies. The idea of development has been theorised and then modified by Western scholars from the stages of development established by Millikan and Rostow (2015) during the 1950s to the Human Development and Capabilities Approach and 'Sustainable Development' promulgated by Amartya Sen (PNUD 2011) since the late 1980s. These changes have been made not only because of the evidence that development policies had poor results but also due to the socio-economic and political world transformations, such as the (political) decolonisation of the impoverished countries, the demise of the socialist bloc, the so-called 'globalisation', the securitisation of foreign aid or the increase of migratory flows.

A reading of the most relevant texts on development since 1945 suggests that a lack of analysis exists on the root causes of poverty and inequalities and that the analysis that does exist is full of abstract definitions. ${ }^{5}$ This article takes the definition of development set out by the Agenda for Development of the United Nations as a starting point to enable the construction of an alternative and critical analysis of what development policies are. The Agenda defines 'development' as a "multidimensional undertaking to achieve a higher quality of life for all people", with references to the economic and social development and environmental protection made through "sustained economic growth", "democracy, respect for all human rights and fundamental freedoms" as well as "the empowerment of women" (UN 1997, 1-2). Similarly, in the Resolution of the General Assembly of the UN in 2015 about the 2030 Agenda for Sustainable Development, we find proclamations of justice, prosperity, peace, ethics and vague references to what development means as well as great declarations such as "leaving no one left behind" (UN 2015b).

In these texts, the Western idea of "global justice" emerges. Dubois (2000, 8-14) notes that the 'ethical element' of development cooperation turns out to be eventually subordinate or subject to the economic interests of donors; the most obvious consequence is that what is called 'solidarity' ends up being 'a modern charity'.

Most of these analyses, in short, are incomplete or undetailed, carried out from the Western point of view, full of abstractions and deeply normative pseudo-definitions. Some of the reasons will be presented throughout this article.

\footnotetext{
${ }^{5}$ In addition to these texts, it is worth reading Truman (2015), Nussbaum (2015), and in general the OECD and UN Declarations on development over the last decades. Especially relevant to understanding the terminological evolution of development studies is Absell's work (2014) on the lexicon of development.
} 


\section{Hackneyed roads and sterile evidence}

Most development studies focus on a number of issues of some relevance, but they are constantly repeated. These debates generate some change but above all show evidence about the problems that have affected development policies for decades.

Among the main points of the current debate that serve the objectives of the article is firstly the impact of foreign aid, a central aspect for evaluating development policies and the relevance (or irrelevance) of these policies. The main studies carried out so far (Alonso et al. 2011, Clemens et al. 2012, Minoiu and Reddy 2010, Arndt et al. 2015) present contradictory evidence: some studies highlight a positive relationship between development policies and the growth of impoverished countries, mainly with regard to the increase of capacities, investment and government resources. These studies disagree on whether there is a positive impact in the short or long term and on whether this relative impact has the same effect on countries with a greater or lesser dependence on aid. A second group of studies, such as those by Dalgaard et al. (2004), Rajan and Subramanian (2008) have not been able to establish reliable relationships between development policies and economic growth (Alonso 2014, 174). Finally, there is a group of authors, such as Djankov et al. (2008) and Moss et al. (2006), who have shown the direct negative result of development policies. Doucouliagos and Paldam (2010) perform a meta-analysis of more than 105 studies in this regard and find that the aid has negative effects on saving and investment and a positive but almost neutral effect on growth. Of all these studies, it cannot be affirmed that development policies have a clear, large, long-term and sustainable positive impact on the "development" of impoverished countries, even less in the most deprived ones.

A longstanding discussion in development studies is about aid effectiveness. There are some authors (Easterly 2015, Moyo 2011) who base their analysis on the consequences and not on the causes of social and economic inequalities, who defend that aid should be more limited and focus on capability-building actions in 'developing countries' instead of providing them with solutions.

Other hegemonic studies (e.g. Sachs 2015) as well as the Development Assistance Committee (DAC) of the OECD, claim that more aid flows are needed, based both on the needs of the impoverished countries and on a better division of labour among donors (harmonisation). There are also studies that call for greater involvement of the impoverished "partners", in alignment with the needs of these countries to improve the effectiveness of aid (Freres and Novales 2016).

Finally, there are authors who think that aid should be "ditched", arguing that it is the market and trade that will make development possible (Engel 2014), while Acemoglu and 
Robinson (2012) continue grounding their analysis on the consequences and not on the causes, blaming the underdevelopment of the vast majority of countries and people in the world to factors such as the existence of weak institutions, the harassment of free competition, the lack of technologies or incentives for investment as if the institutions or technology were the inventors of the economic system and not the expression of its needs and functioning.

Although these discussions have generated some changes in the development policies, as indicated by Alonso et. al (2011), these studies could be characterised as self-referential, lacking a transdisciplinary approach that would explain the roots, causes and effects of these policies, and promoting capitalism "as the only path out of poverty" (Engel 2014, 1375).

\section{Some conclusions about the current discussion on development policies}

The fact is that the same issues have been discussed for decades, with very little theoretical ground or tangible and sustainable results. Some inequalities are temporarily reduced, others grow while many others are not taken into account. The ever-present impression that all advances can be lost if the economic situation changes should be considered a warning sign that lead us to think that these studies are missing the point. The problems on which development policies are intended to address are not solved in the current economic framework while the real factors that generate inequality and injustices in the world are overlooked. In this line, Sogge $(2004,63)$ states that these discussions are in fact "a theatre of shadows", which serves to simplify the causes of global inequalities or to hide them.

The following sections will attempt to point out new insights of research in this regard, concisely offering a new framework of analysis of development policies from the point of view of Marxism and decolonial studies and introducing concepts such as charity discourse and development imperative as the ideological foundations of development policies.

\section{Repositioning the debate: Development policies as an inherent phenomenon of the capitalist system}

\section{The economic dimension of development policies: Contribution to the extensive and intensive expansion of capitalism}

To understand the relative importance of development policies and international aid in the economic scope, both must be characterised as social processes inherent to the capitalist system. This topic has not been sufficiently addressed by development studies, and in general it has been superficially covered, mainly by some authors related to Marxism and decolonial studies. In this way, Maestro and Martínez $(2012,814)$ place development cooperation "as an integral part of the global economic structure, and therefore inseparable from the structure and domination 
dynamics of the global capitalist mode of production, distribution, circulation and consumption, over any other forms of production and reproduction in the world".

Development should be intended in this sense as the development of the capitalist system. In economic terms, this means that development policies respond to the necessity of the capitalist system to consolidate extensively and intensively "the integration of territories, individuals and activities in the sphere of global capitalism" (Maestro and Martínez 2012, 816); and, on a secondary level, to the alleviation of the inequalities that the system generates by its own dynamics.

Without going into too much detail on the mechanisms of operation of the capitalist mode of production (which far exceeds the objectives of this article), when it comes to studying development policies, it is worth mentioning several concepts on which global capitalism is founded and which may help to explain the extensive and intensive growth of this system, in which development plays a relatively relevant role.

The first notion is the general law of capitalist accumulation. Marx, in his work Capital, demonstrated that capitalism bases its function on the appropriation of surplus value generated by workers, due to the private ownership of the means of production. This surplus value, that is the generation of capital from the activity of workers, is used for capital accumulation either through the purchase of labour power or means of production, which will be used to reproduce not only goods but also to ensure social order under a network of institutions and practices (Marx 1975a). Under this law, the accumulation does not cease, which partly explains, on the one hand, the interminable expansion of capital on an international scale, thanks to the generated surplus value and the need to place the generated stock in the market, and on the other hand, the growing proletarianisation of the world population, which has been gradually introduced into the capitalist mode of production for centuries.

Another critical concept refers to 'primitive' accumulation or accumulation by dispossession. The genesis and subsequent development of the capitalist system is characterised by a process of appropriation and usurpation of lands, monopolisation and concentration of capital, transformation of non-capitalist property into capitalist, and in general, the process by which the means of production have passed to private hands (Marx 1975a, 894-896). This process began in Europe in the $14^{\text {th }}$ century and has spread ever since throughout the world, regardless of any other mode of production and social structure that has ever existed. It is important to mention that this process has not concluded and that it is never peaceful (among other factors, because of the class struggle of the people who are affected by this process, and who sometimes manage to reverse it). 
This process of accumulation means, on the one hand, an extensive expansion of the capitalist system geographically, which means destroying other modes of production and social structures; and, on the other hand, an intensive expansion, which means reaching all possible productive sectors or using low-wage workforce. It is, therefore, an essential process for the reproduction of the capitalist system and what explains its international dimension since the beginning of the $16^{\text {th }}$ century.

The international division of labour between centres, peripheries and semi-peripheries, which makes up what has been called the world-system approach (Wallerstein 2012), are crucial phenomena related to development policies, as it expresses the social structures formed from the early times of the capitalist system and it is intimately linked to the process of economic and cultural colonisation (Castro-Gómez and Grosfoguel 2007, 13).

This world-system approach, directly derived from black Marxism schemes, and further theorised by Western authors like Wallerstein (2000), is useful to analyse and explain several current trends in the system: 1) the accumulation of capital on a global scale; 2) the generation of a growing (extensive) proletarianisation and a sexual (Federici 2016) and racial (Quijano 2001) division of labour, with consequently different remunerations based on gender and race; and 3) the creation of extended global commodity chains, where most of the exchanges take place. This determines what the centres of the system are, that is, where the end of the production chains, controlled by transnational companies, is located; the semi-peripheries, which are increasingly controlling the intermediate processes and some initial chains; and the peripheries, where production chains originate (Wallerstein 2012, 18-25).

On this basis, one of the main proposals of this article is that development policies and international aid should be framed in the logics and changes of the capitalist system. In this sense, some of the main characteristics of development policies and development cooperation at a global level can be briefly noted. Firstly, development policies in general and development cooperation in particular contribute to the continuous process of global capital accumulation. In order to ensure its intensive and extensive expansion, the capitalist system has to continue with the process of opening markets that were not incorporated into the global production chains and thus try to reduce the effects of the tendency of the profit rate to fall which thereby increases the proletarianisation of social strata (Wallerstein 2012, 17-18).

The contributions of development policies to this process are several, mainly: 1) through the application of financial instruments such as microcredits, business development services, the promotion of industrial and mining policies, the introduction of new agricultural techniques and the extension of agribusiness; or 2) by keeping the control of technologies to implement certain 
basic services, such as water supply and sanitation, infrastructures, energy and renewal sources, health, among many others.

Secondly, populations that had non-capitalist modes of production have been introduced to the system through — among others means - development policies in recent decades. This process has been far from peaceful and consensual; on the contrary, it has been the consequence of the imposition of structural adjustment policies since the late 1980s, driven by major development funders, such as the World Bank, the International Monetary Fund and even the UN (Federici 2016, 73).

Moreover, development policies are carried out mainly by the central countries of the capitalist world-economy and by some of the semi-peripheral countries but based on different dynamics. This is particularly true for development aid, in which the DAC countries define what official development aid (ODA) is, which sectors to promote and which approach should be given to ODA. Development policies are, therefore, developed by Western countries almost exclusively.

It is important to underline that development policies are subject to the economic policies of the core countries and their priorities, despite the search for a 'policy harmonisation' that is never achieved. As Sogge indicates $(2017,32)$, the fact that "many donor policies imposed in the name of equitable development have generated unimpressive and even counter-productive effects (such as weakening public management and services)" has had, on the other hand, benefits for those that have taken control of those sectors, namely transnational companies but also NGOs, social enterprises and foundations.

Ultimately, development policies seek to reverse the inequalities generated by the expansion of the capitalist system on a global scale, but in no case do they achieve this. Although the Sustainable Development Goals (SDGs) seek to literally put an end to poverty and hunger in the world by 2030, the latest study on inequality by Oxfam (2019) draws attention to the unbridled increase in inequality in terms of income since 1980, at the beginning of the neoliberal era of capitalism. Nowadays only 26 people in the world have the same wealth as $50 \%$ of the population (Oxfam 2019, 28), and the vast majority of people who have been lifted from poverty in the recent decades come from China, India and Southeast Asia, while poverty has increased in subSaharan Africa since 2013. It seems clear, therefore, that if development policies are subordinated to the economic trends of the capitalist system, their declared aim of reducing poverty and inequalities is unlikely to be reached.

All that has been mentioned so far allows us to point out, on the one hand, that the capitalist system generates asymmetries on a global scale due to its own dynamics, causing 
inhuman economic, political, social, gender and ethno-racial inequalities; and, on the other hand, that development policies, as a specific process framed in the capitalist system, contribute to these trends rather than reverse them. Capitalism is indeed always developing. However, it is an 'unequal development', which, as indicated by Maestro and Martínez $(2012,820)$, generates structural asymmetries between centres and peripheries in terms of extraversion (the export of the capital gains of the global commodities chain towards the Western countries) in obvious contradiction with the idea of generating self-sufficient economies in the peripheries of the world-system, one of the acknowledged objectives of development policies. To detract from this fact is one of the main tasks of the ideological component of development.

\section{The non-profit industrial complex - Current economic trends in development}

Development policies are not materialised only through international aid. In fact, this is one of the smallest flows, moving around 99,000 million dollars in 2017 by the member countries of the DAC (OECD 2019a). Since the so-called cooperation crisis of the $1990 \mathrm{~s}^{6}$, other private flows, such as foreign direct investment and trade in general, are the prioritised funding sources for 'development', while aid would be requested only in case of market or government 'failures'.

Development policies are being increasingly privatised. The presence of mechanisms, such as the Aid for Trade or the creation of Global Funds, draw attention to the increasing participation of the large corporations in development aid (Sogge 2017, 30). In fact, both in the 2030 Agenda (UN 2015b) and the last Financing for Development Conference, held in 2015 (UN 2015a), the reference to the need for private funds is almost seen as a requirement, within a context in which the aid given by the DAC member countries is practically stagnant around 0.3 $\%$ of their GDP (OECD 2019a), far from the $0.7 \%$ that is considered an appropriate level.

As development policies contribute to the economic expansion of the system, large corporations want to participate. This fact should not be surprising. One of the current dynamics of capitalism in its neoliberal phase is the process of 'accumulation by dispossession', by which there is an increasing privatisation and commodification of goods and properties (Harvey 2005, 167), expressed in the return to private hands of sectors and goods that once were in the hands of the States, or under any another mode of production different from the capitalistic one. This process is led by the main economic complexes, that is, the transnational private sector.

However, this accumulation by dispossession is not only directed by private companies. In recent years the concept of non-profit industrial complex has been coined (Rodríguez 2017),

\footnotetext{
${ }^{6}$ The crisis refers to the significant decline in proportion of official development assistance (ODA) by the OECD states, as well as the beginning of the debate on the effectiveness of ODA. All this occurred in a context of strong neo-liberalisation of the economy (Washington Consensus) and the subsequent brutal increase in inequalities worldwide (see Perroulaz et. al 2010 and Sotillo 2011, 141-177).
} 
constituted by those who execute the development policies, that is, the large international financial institutions (World Bank, regional development banks, International Monetary Fund), development aid actors (UN, EU, richest countries), private funds for development (mainly through foundations created by the largest transnationals) and NGOs ${ }^{7}$. As Gürcan (2016) argues, this complex is an integral part of the contemporary global capitalist system and is closely linked with the processes of accumulation by dispossession that has intensified since the 1970s, resulting in the privatisation of social services, now managed by so-called non-profit organisations. These services provided by non-profit organisations are more exclusive, volatile and less comprehensive than those previously provided by the State, since they are dependent on external (private) funding (Petras 1998, 13).

In this sense, according to data from OECD (2019b), the NGOs passed from managing 49 million dollars of ODA in 1977 to over $\$ 15$ billion in 2018, which highlights their increasingly relevant role in this sector. This statement is reinforced by the fact that, by 2010 , more than 600 million people in the world had been assisted by an NGO (Barry-Shaw and Jay 2012, 16). Furthermore, the philanthropic foundations born out of the biggest transnational companies "provided USD 23.9 billion for development in 2013-15, or USD 7.96 billion per year on average" to development actions (OECD 2018, 5). Not surprisingly, the majority of foundations and large NGOs are American or European. A brief example that can synthesise the role of development policies in the production and reproduction of the capitalist system is the use of one of the tools fostered by development policies in a country: microcredits in Bangladesh.

Bangladesh in the early 1980s was a poor and dependent country, which was becoming increasingly integrated into the global production chains of the capitalist system. At the beginning of the 1980s, struggles and debates arose among a large part of Bangladeshi society, still mainly dedicated to agriculture, which demanded an agrarian reform, that is, a greater distribution of land and thus an improvement in the living conditions of the peasantry, since it was understood that rural poverty originates from an unequal distribution of land. On the other side, the main development actors (development banks and agencies, OECD, NGOs), defended that peasants' poverty was due rather to their very limited access to the credit market (Gürcan 2016, 126). This last view was the dominant one.

As a consequence, populations that did not work under capitalist production relations entered the (micro) credit market. This supposed, firstly, that from that moment a good part of their means of production (seeds, instruments) had to be acquired with credits. Secondly, there

7 LGBTIQ organisations, human rights associations, indigenous groups or other protest movements are not considered here as part of the non-profit complex, for one reason: their main political objectives would have a negative impact on the system, while non-profit organisations actually contribute to its expansion. 
was a process of proletarianisation as these peasants became borrowers, since until then they had not integrated into the capitalist system. This proletarianisation meant a migration from the countryside to the city and its industries, which is a factor that contributed to making Bangladesh one of the main nodes in the production of commodities for the world consumption (and therefore, contributed to the continuous process of global capital accumulation).

Remarkably, every year the main development actors support microcredits as a development tool. It is better to finance microcredits than to enact an agrarian reform, which would be accompanied by non-desirable political changes. In this sense, it is estimated that the vast majority of the 2,000 NGOs present in Bangladesh are dedicated to microcredit (Gürcan 2016, 126).

\section{The ideological dimension: Social control and global hegemony}

If development policies and the non-profit industrial complex are fundamental factors for the expansion of the capitalist system at a global level and the impact of these policies is very low, null or negative in terms of putting an end to inequalities, the question of why there is a generalised assumption that development policies help to combat injustices and inequalities arises. Moreover, why are development policies criticised but at the same time maintained? Studying the ideological factor of development will offer new research ways to respond to these and other issues.

\section{Ideology and the charity discourse}

Marxist theories argue that ideologies are the expression of a certain historical mode of production in a system of ideas which materialise in laws, politics, social practices, policies and institutions and which are a fundamental element for the reproduction of the system (Gramsci 2017, 222-233). The so-called dominant ideology is the expression of the ideas and interests of the ruling classes and their fractions (Gramsci 2017, 201-203), and takes shape in political, religious, and educational institutions, but also in charity institutions and discourse, an aspect that is an open field in development policies and one that will attract our attention in this article.

As Žižek $(2003,15)$ points out, through ideology what matters is not so much its specified content as such but how it is functional with respect to relations of social domination, that is, the logic that legitimates the relationship of domination, which always appears hidden in the discourse. This does not mean that there is a discourse outside the discourse, but that there is no neutral descriptive content, since all discourse is at the same time descriptive and argumentative. However, what ideology does is precisely to represent the hegemonic discourse as something neutral, even as something natural. This is one of the distinctive features of the liberal-capitalist ideology and the Modernity project initiated in the sixteenth century (Lander 2000, 6-7). Aspects 
such as private ownership and private control over the means of production, Western morality as a universal value or the claim of an objective and neutral science are critical assumptions upon the dominant ideology and hegemonic discourse are built but are at the same time absent or presented implicitly, precisely to hide those parts of the discourse that would be problematic for justifying the domination.

Just as there is a number of institutions dedicated to shaping and implementing development policies (encompassed in the non-profit industrial complex), there is also a specific type of discourse that is channelled through these institutions, which in this article will be referred to as charity discourse. This concept allows us, firstly, to identify the main features on which capitalism constructs a domination device under the pretext of charity (not solidarity, which would result in and as a result of more equitable relations). Secondly, it enables us to make an analysis with a historical perspective, comparing how the discourse of charity has been modulated throughout the historical development of capitalism. Since the economic and ideologic dimensions are imbricated, development policies as well as the non-profit industrial complex are the instrumental channels for the central countries to exercise hegemony and impose the dominant ideology through the charity discourse and thereby ensure the reproduction of the system.

Charity discourse, consequently, should not be misled with ideas of development. This discourse precedes the concept of development and includes more social and cultural dimensions than those covered by development policies, which respond to the current logic of the capitalist system. It is very likely that some ideas and practices of development will disappear in the future as they will be substituted by others. But charity discourse, as an ideological device of the capitalist relations of production, is a historical necessity, since these relations produce several harmful effects (poverty, inequality) that must be hidden to ensure the reproduction of the system.

\section{The development imperative as an expression of the charity discourse}

Development and its variations over the last decades are the ideological imperative that unites all the actors that constitute the non-profit industrial complex. But is there any satisfactory characterisation of what development is? Rist $(2002,21)$ draws attention to the lack of an unequivocal definition of development. Elaborated mainly by the UN or Western think tanks, these aspirational definitions share a normative character and do not express any concrete reality. However, they promote an ideal state that must be reached, since development is a 'universal' ambition that all cultures should share.

This imperative is one of the principal current expressions of the charity discourse and it is not entirely new, since it is aligned with the Western idea of progress, very relevant for the 
development of the bourgeois-capitalist ideology as well as with Modernity (Mignolo 2007, 26). Development would be a transfiguration of the Western myth of progress, coupled with the idea of charity; overlapping concepts that have been expressed in different ways throughout the development of the capitalist system.

However, reality differs from what is defined as an ideal state that may be reached in the near future, which is the general assumption of what 'development' is. In this sense, ideology "does not represent the existing relations of production (or the other relationships that derive therefrom) but above all the (imaginary) relationship of individuals with the relations of production and the other relationships that result from it" (Althusser 2003, 141). Rist's definition of development points precisely to that direction:

Development consists of a set of practices, sometimes appearing to conflict with one another, which require — for the reproduction of society — the general transformation and destruction of the natural environment and of social relations. Its aim is to increase the production of commodities (goods and services) geared, by way of exchange, to effective demand (Rist 2002, 24-29).

This is the definition that we consider most appropriate when it comes to defining development; therefore, it is the one that is adopted in this article. It is important to pause briefly on several aspects of this definition.

Firstly, the definition highlights that development policies' tools ensure social reproduction. Development can therefore be seen as part of the charity discourse which helps reproduce the capitalist system.

Secondly, anti-capitalist or non-Western social relations are destroyed as a result of these practices, which allows for the extensive and intensive development of capitalism. Similarly, the consequences of the historical development of capitalism and the colonisation of America, Africa and Asia are buried in the official discourse on development.

Lastly, these practices are destructive for the environment, as they are imbricated in the logic of a capitalism which is based on the axiom of interest and profit and not on the management of sustainable resources and production. According to WWF $(2018,22)$, all the resources that the Earth produces for a year are actually consumed around mid-year which shows the inconsistency of the development imperative with the reality of the system. Despite this contradiction (or because of that), the current general speech has switched to 'sustainable development'.

Rist sustains that development is a belief which leads us to inscribe it within the current hegemonic capitalist ideology and the charity discourse that catalyses it. A belief is different from ideology because it is a collective certainty beyond all rejoinder, very effective for the reason that 
it may be doubted in private but it must be affirmed in public, because it represents a hope (faith) of something better to come although everything points to the opposite. Likewise, belief is also different from ideology because it is not easily refutable, absorbs contradictions more easily, and ultimately because contradictory assumptions can be assumed without questioning the core of the belief (Rist 2002, 32-35).

This belief in development, operating as an ideological imperative, is intimately linked to the ideas of Modernity and progress, present in much of Western thought, which has accompanied the development of the capitalist system over the past centuries. According to Lander $(2000,10)$, the European capitalist Modernity classifies societies in many ways including the concept of developed and undeveloped societies. This belief naturalises the specific social relations derived from the capitalist system, it does not discuss the origin or conditions of its development, whether capitalist relations are just or unjust or if they generate inequalities.

These ideological processes are imbricated in what decolonial studies termed 'coloniality'. This is very relevant for the charity discourse, development and aid, given that the world-system was constituted not only under the need for global capital accumulation, but also mixed "with the racist, homophobic and sexist discourses of European patriarchy. The international division of labour linked a series of hierarchies of power: ethno-racial, spiritual, epistemic, and genderbased" (Castro-Gómez and Grosfoguel 2007, 19). The decolonial studies claim that these colonialities, expressed in the spheres of power, knowledge and being, have not ended. On the contrary, they remain fully in force and are directly related to development practices (Mignolo 2007, 27).

Characterising the non-Western world as not sufficiently developed, with archaic, premodern societies, and therefore in need of support, justifies the domination of the central States and imperialist logic (Castro-Gómez and Grosfoguel 2007, 14). Development policies cannot be dissociated from this discourse. In this way, the ideology of Modernity and the consequences of the capitalist economy will never be questioned in the current reference texts on development (Mignolo 2007, 25), such as the Sustainable Development Goals. In these documents is favoured to talk about the harmful effects of the system, which development policies are supposed to alleviate. In this sense, progress and development are something natural, applicable to all, universal, inexorable, ineluctable.

\section{The non-profit industrial complex: the catalyst of the dominant ideology}

As explained above, development policies are aligned and subordinated to the needs of the capitalist system. In the ideological realm, the non-profit industrial complex, constituted by numerous actors, such as the UN, the OECD, the EU, economic fora such as the G20, 
foundations and NGOs, acts as the catalyst for charity discourse, an ideological device that operates globally, channelling the dominant ideology into concrete actions through these actors. Its aim is to convey the idea that it is an ethical imperative of the West to help the neediest countries, without questioning why they are poor, and hiding several facts. These facts include the following: 1) the capitalist mode of production is the one which generates those inequalities; 2) the institutions that finance development policies and actions ensure, in the first place, the global economic interests of the system; 3) Western countries, as the central States in the world-system, are actually responsible for the impoverishment of the peripheral and semi-peripheral countries; 4) development policies use the pretext of aid, and even solidarity, as abstract defences to extend the economic, political and cultural domination of the West; and 5) development policies will not succeed in ending inequalities.

In this way, Rodríguez $(2017,22)$ argues that this complex is "the set of symbiotic relationships that link together political and financial technologies of the state and owning-class proctorship and surveillance over public political intercourse", mainly against leftist social movements.

In this non-profit industrial complex, there is a symbiotic relationship between foundations, NGOs, companies and the State. This is particularly clear in the case of NGOs, mainly financed by the State and companies in exchange for implementing social services previously carried out by the State - at a major cost (in the case of the central countries) - or not implemented at all (in peripheral and semi-peripheral countries). The work of NGOs is carried out under the conditions established by the donors in the sectors and countries that establish the calls, implicitly or explicitly accepting the conditions, approaches, principles and values of those who finance the services or projects.

In the neoliberal era, the system rewards foundations and NGOs above other organisations with a more explicit anti-system purpose, with the political objective of taking control of the state to make structural changes. In this scenario, NGOs have come to manage dissent, dissidence or desire for social change (Choudry and Shragge 2011, 507). Therefore, injustices and political issues are managed through organisations with no intention of fighting against established powers - because they are funded by them. As a result, their actions are far from endangering the economic or social relations of the capitalist system. On the contrary, they contribute to maintaining and spreading the hegemonic discourse and ideology, while increasing professionalisation and depoliticisation of the NGOs (Choudry and Shragge 2011, 506).

Although historically the first NGOs had a social base rooted in the idea of a global "social justice", today they are disconnected from their original social base and connected instead 
with the structures of power. This fact has, in short, clear consequences. Firstly, the fight against injustices is channelled through the same system that generates them. Secondly, there is a "recolonisation" (in the opinion of Choudry and Shragge) and an exacerbation of neo-colonialist standpoints in the impoverished countries, where local organisations assume the neoliberal discourse if they want to raise or attract funds from Western organisations, leaving aside any questioning about the logic of the economic, political, sexual and social powers that affect them. Thirdly, there is a fragmentation process of social movements at all levels. As a result, local contestation struggles are not connected with each other, nor with the main global struggles, while the non-profit industrial complex operates globally. In this line, some causes considered fair are defended, while others, more radical, are denied. Therefore, some fragments of the discourses that fight against inequalities and injustices are assumed by the dominant ideology and discourse, while the other parts that may put the system at risk are discarded.

Accordingly, the majority of the civil society actors are embracing the so-called "ideology of pragmatism" (Choudry and Shragge 2011), which, in the end, is a functional attitude where the dominant ideology is not explicitly confronted.

This same pragmatism calls for "social change" in most mainstream documents about development, giving at the same time a static view of social relations, ignoring conflicts or redirecting them to "changes" that do not pose a structural threat. Reports from NGOs or United Nations agencies thus commonly affirm that, if current social trends continue like nowadays, for example, "It will take 104 years for Chad to reduce under-five mortality rate by two-thirds with current tax evasion rates" (Oxfam Intermón 2015, 10). Such an assertion seems to condemn impoverished countries to resignation, unless there is a very unlikely change in the system. A global taxation is claimed by Oxfam as a feasible decision, but we argue it would go against the logic of capital accumulation as would provoke a significant reduction in the rate of profit that would be unbearable for transnational corporations and would never be supported by core states.

The contradictions of development discourse are revealed in the example of eradicating world hunger. It is revealing that the 1974 FAO World Food Conference proclaimed that in ten years no child would starve. The 1996 World Food Summit delayed this goal until 2010 (FAO 1996). And now the SDGs claim there will be "zero hunger" in 2030 (UN 2015b). The reality is that today more than 1.7 billion people suffer from hunger in the world. After all, as Fukuda-Parr $(2012$, 2) emphasises when talking about the Millennium Development Goals, those should be "understood as a narrative -rather than as a development strategy". 


\section{Alternative and critical paths to development: Global justice and capitalism}

The main proposition in this article is that development policies are not really fighting against global inequalities and against injustice. Instead, they are an inherent element of the global capitalist system which generates the inequalities they are supposed to alleviate. Through ideology and charity discourse, development policies and institutions impose an idea of justice in which these inequalities and violations of the rights of millions of human beings are not linked with the general functioning of the capitalist system.

Therefore, the question of whether there is any way that development policies may avoid reproducing global poverty and inequalities arises. Given that the research routes exposed in this article have not been exhaustively touched on other studies, there are only a few authors who have ventured to offer answers or alternative research methods.

Post-development studies perhaps offer a more structured critique to development, incorporating a hybrid proposal between Western capitalist Modernity and local knowledge, but is mainly focused on rising above the Modernity paradigm and what it entails, such as economic and cultural colonialism, in search of preserving diverse societies with different discourses and representations, and therefore with different knowledge production centres (Escobar 2005). In practical terms, the concept of "counterwork" is advocated, that is, the resistances posed by a diversity of peoples throughout the world against development, without there being a universal response to development.

Despite incorporating interesting elements, such as the proposal to focus on the struggles of the people and local knowledge to overcome the effects of Western modernity, postdevelopment studies do not offer a clear path of how to do it, how these changes will be achieved at a political or economic level, probably because it is not considered the most important path to take.

Among anti-capitalist positions, Llistar (2009) proposes several measures to try to ensure that development cooperation responds to global problems and the interests of the social majority. In the first place, development aid should be "redefined", based on a peer-to-peer relations and not donor-recipient, which is the current prevailing logic. Instead, aid would be more effective in financing campaigns of political advocacy and pressure on the causes of poverty, war or ecological damage, always under the excuse of "global justice". The main actors would be NGOs from the North, which would be at the service of NGOs of the Global South.

As a criticism, it seems obvious to claim that no actor in the non-profit industrial complex would finance political movements whose purpose is to end the capitalist economic and political 
regime. Thus, anti-system organisations are unlikely to obtain funds from governments, private foundations, banks or any other actor to explicitly short-circuit the system.

A more structured proposal is made by Maestro and Martínez (2012), who coined the term "anti-system aid", consisting in the subordination of external needs (production and reproduction of capitalism) to the internal needs of each country. For this to be possible, these authors argue that it would be necessary to generate changes in two areas: in the world-system, in order to abandon the extractive logic of resources from the peripheries to the centre, by "confronting" capitalism and fostering a "solidarity globalisation"; and at the internal level of the countries, advancing towards a social democracy at the service of the working class and keeping the sovereign of their own resources. This 'anti-system aid' would have "the same practices", "as well as necessarily new ones", to "cut the noose and generate riot conditions" (Maestro and Martínez 2012, 817).

Despite the suggestive idea of "anti-system aid", this analysis falls into idealism, because if development cooperation is embedded in the capitalist system, this means that there is not an anti-system option. Under the conditions of the capitalist system, another type of cooperation that is more horizontal and based on internal, non-external needs seems unlikely, although the possibility of cooperation among non-capitalist countries would be possible. However, this would not be called "development cooperation".

In view of what is stated throughout the article, it is not evident that the solutions presented above are realistic, nor that they succeed in attacking the pillars on which global capitalism is based. Most of these alternative proposals are also based on abstractions such as global justice, solidarity globalisation, and the same language is used as in the development studies. In addition, they do not present feasible proposals or concrete actions, which makes difficult to consider these proposals as true alternatives to development and international aid.

There is probably no alternative within the system to the discourse and practices of development because it is an internal characteristic of the capitalist system of Western Modernity. In this sense, neither development cooperation nor its hypothetical alternative alone will put an end to global inequalities. The alternative would probably go through a profound systemic change, that is, an anti-capitalist political proposal (or several proposals, mainly from peripheric states or by subaltern groups), aimed at subverting the current capitalist regime in order to generate real alternatives that overcome the current situation.

\section{Conclusions}

Faced with the exhaustion of traditional discussions on development and international aid, this article studied development policies from an alternative and critical point of view, trying 
to determine other causes for why development policies exist and how they function. In order to do so, this article conducted a historical, economic and ideological analysis of development policies and aid and situated them as an inherently capitalist and Western phenomenon. The section about the economic dimension of development policies highlighted the role of these policies within the development of the capitalist economic system and situated the non-profit industrial complex as the executing arm of these policies. Public-private alliances, micro-credits, institutional strengthening, aid for trade, gender equality policies (that do not suppose eroding patriarchy), reduction of polluting gases and aid for entrepreneurship are the face of the development coin. The discourse of (sustainable) development, progress, the ethical imperative of help, the fight against injustice without changing the economic base that generates inequalities represent the reverse side.

The charity discourse and the imperative of development, identified as a belief linked to Western Modernity and the idea of progress, are ideological mechanisms that allow the capitalist system to continue accumulating capital on a global scale and generating inequalities while simultaneously selling the idea that actions are being taken against inequalities and injustice. To ensure this process, the executing arm of the charity discourse, the non-profit industrial complex, is indispensable, even in those organisations that seem to do everything possible to put an end to these inequalities.

The current discussions in development studies continue with the eternal debate, the theatre of shadows in which the crucial points that generate inequality and injustices on a global scale are not touched and in which the true interests of these policies are hidden. In this sense, the insights provided in this article are an invitation for future studies and critical actions to examine in greater depth what the general economic trends of development policies are and how to best characterise the charity discourse on which development policies are constructed.

\section{References}

Absell, Christopher David. 2014. "The Lexicon of Development: Quantitative History of the Language of Development Studies." Revista Iberoamericana de Estudios de Desarrollo 4 (1): 4-35. https://doi.org/10.26754/ojs ried/ijds.120

Acemoglu, Daron, and James A Robinson. 2012. Por qué Fracasan los Países: Los Orígenes del Poder, la Prosperidady la Pobreza. Translated by M. García Madera. Barcelona: Deusto.

Alonso, José Antonio. 2014. "Eficacia Agregada de la Ayuda: Incidencia sobre el Crecimiento del Receptor." Revista de Evaluación de Programas y Políticas Públicas 3: 154-188. https://doi.org/10.5944/reppp.3.2014.13364

Alonso, José Antonio, Carlos Garcimartín, and Víctor Martín. 2011. "Ayuda, Calidad Institucional e Impuestos: Algunos Desafíos para el Sistema de Cooperación Internacional." 
In Cooperación para Desarrollo en Tiempos de Crisis, edited by José Antonio Alonso and José Antonio Ocampo, 189-258. Madrid: Fondo de Cultura Económica de España.

Althusser, Louis. 2003. "Ideología y Aparatos Ideológicos de Estado.” In Ideología: Un Mapa de la Cuestión, edited by Slavoj Žižek, 115-155. Translated by F. Sazbón. Buenos Aires: Fondo de Cultura Económica.

Arndt, Channing, Jones Sam, and Tarp Finn. 2015. "Assessing Foreign Aid's Long-Run Contribution to Growth and Development." World Development 69: 6-18. https://doi.org/10.1016/j.worlddev.2013.12.016

Barry-Shaw, Nikolas, and Dru Oja Jay. 2012. Paved with Good Intentions-Canada's Development NGOs from Idealism to Imperialism. Halifax: Fernwood Publishing.

Castro-Gómez, Santiago, and Ramón Grosfoguel. 2007. "Prólogo. Giro Decolonial, Teoría Crítica y Pensamiento Heterárquico." In El Giro Decolonial: Reflexiones para una Diversidad Epistémica más Allá del Capitalismo Global, edited by Santiago Castro-Gómez and Ramón Grosfoguel. 9-23. Bogotá: Siglo del Hombre Editores/IESCO-UC/Pontificia Universidad Javeriana. http://www.unsa.edu.ar/histocat/hamoderna/grosfoguelcastrogomez.pdf

Choudry, Aziz, and Eric Shragge. 2011. "Disciplining Dissent: NGOs and Community Organisations." Globalizations 8 (4): 503-517. https://doi.org/10.1080/14747731.2011.585855

Clemens, Michael A., Steven Radelet, and Rikhil R. Bhavnani. 2012. "Counting Chickens When They Hatch: The Short-Term Effect of Aid on Growth." The Economic Journal 122 (561): 590617. http://dx.doi.org/10.2139/ssrn.1112709

Dalgaard, Carl-Johan, Henrik Hansen, and Tarp, Finn. 2004. "On the Empirics of Foreign Aid and Growth." The Economic Journal 114 (496): F191-F216. https://doi.org/10.1111/j.1468$\underline{0297.2004 .00219 . \mathrm{x}}$

Djankov, Simeon, José Montalvo, and Marta Reynal-Querol. 2008. “The Curse of Aid.” Journal of Economic Growth 13 (3): 169-194. https://doi.org/10.1007/s10887-008-9032-8

Doucouliagos, Chris, and Martin Paldam. 2010. "The Ineffectiveness of Development Aid on Growth: An Update." European Journal of Political Economy 27 (2): 399-404. http://martin.paldam.dk/Papers/Meta-AEL/6-Meta-G-Update.pdf

Dubois, Alfonso. 2000. "Equidad, Bienestar y Participación: Bases para Construir un Desarrollo Alternativo. El Debate sobre la Cooperación al Desarrollo del Futuro." Cuadernos de Trabajo de Hegoa 26: 1-64. https://www.ehu.eus/ojs/index.php/hegoa/article/view/10798/10072

Easterly, William. 2015. La Carga del Hombre Blanco. El Fracaso de la Ayuda al Desarrollo. Barcelona: Debate.

Engel, Susan. 2014. “The Not-So-Great Aid Debate.” Third World Quarterly 35 (8): 1374-1389. https://doi.org/10.1080/01436597.2014.946251

Escobar, Arturo. 2005. "El "Postdesarrollo" como Concepto y Práctica Social." In Políticas de Economia, Ambiente y Sociedad en Tiempos de Globalización. Translated by E. Juhász-Mininberg. 17- 
31. Caracas: Facultad de Ciencias Económicas y Sociales, Universidad Central de Venezuela. https://pdfs.semanticscholar.org/9359/5c8982ebc1ba1f2137cfd7186cb73b0f7081.pdf

Federici, Silvia. 2016. Calibán y la Bruja: Mujeres, Cuerpo y Acumulación Originaria. Translated by V. Hendel and S. Touza. Madrid: Traficantes de Sueños.

Food and Agriculture Organization (FAO). 1996. Declaración de Roma sobre la Seguridad Alimentaria Mundial, November 13. http://www.fao.org/3/w3613s/w3613s00.htm (27 August 2019).

Freres, Christian, and Beatriz Novales. 2016. "10 Años de la Agenda de Eficacia de la Ayuda. ¿Qué Queda de París?’” El País. April 11. http://elpais.com/elpais/2016/04/08/planeta futuro/1460121449 027457.html

Fukuda-Parr, Sakiko. 2012. "Recapturing the Narrative of International Development." UNRISD Research Paper No. 2012-5. Geneva: United Nations Research Institute for Social Development. https://bit.ly/31fw1v9

Gramsci, Antonio. 2017. Gramsci, Escritos. (Antología). Translated by M. Sacristán and C. Rendueles. Madrid: Alianza Editorial.

Gürcan, Efe. 2016. "El Complejo Corporativo-No-Lucrativo. Componente Integral y Fuerza Motriz del Imperialismo en la Fase Financiero-Monopolista del Capitalismo." Monthly Review, Selecciones castellano 66: 1-27. https://docs.wixstatic.com/ugd/58e728 e6a00e7aaace417db0a59fdea65035f8.pdf

Harvey, David. 2005. Breve Historia del Neoliberalismo. Translated by A. Varela Mateos. Madrid: Akal.

Kosík, Karel. 1967. Dialéctica de lo concreto. Estudio sobre los problemas del hombre y el mundo. Translated by A. Sánchez Vázquez. Mexico City: Grijalbo.

Lander, Edgardo. 2000. "Ciencias Sociales: Saberes Coloniales y Eurocéntricos." In La Colonialidad del Saber: Eurocentrismo y Ciencias Sociales, Perspectivas Latinoamericanas, edited by Edgardo Lander, 4-23. Buenos Aires: CLACSO. http://biblioteca.clacso.edu.ar/clacso/sursur/20100708040444/3 lander1.pdf

Llistar, David. 2009. Anticooperación, Interferencias Globales Norte-Sur, los Problemas del Sur no se Resuelven con más Ayuda Internacional. Barcelona: Icaria.

Maestro, Irene, and Javier Martínez. 2012. "La Cooperación al Desarrollo como Parte de la Estructura Económica del Capitalismo Global.” Estudios de Economía Aplicada 30 (3): 811- 836. http://www.redalyc.org/pdf/301/30125274003.pdf

Marx, Karl. 1975a. El Capital. Crítica de la Economía Política. Libro primero: El Proceso de Producción de Capital. Translated by P. Scaron. Mexico City: Siglo XXI Editores. https://webs.ucm.es/info/bas/es/marx-eng/capital1/

Marx, Karl. 1975b. El Capital. Crítica de la Economía Política. Libro Tercero: El Proceso Global de la Producción Capitalista, translated by P. Scaron. Madrid: Siglo XXI Editores.

Mignolo, Walter D. 2007. "El Pensamiento Decolonial: Desprendimiento y Apertura. Un Manifiesto." In El Giro Decolonial: Reflexiones para una Diversidad Epistémica más allá del Capitalismo 
Global, edited by Santiago Castro-Gómez and Ramón Grosfoguel, 25-46. Bogotá: Siglo del Hombre Editores, IESCO-UC, Pontificia Universidad Javeriana. https://doi.org/10.25058/issn.2011-2742

Millikan, Max Franklin, and Walt Whitman Rostow. 2015. "Foreign Aid: Next Phase." In Antología del Desarrollo, edited by Tahina Ojeda and José Ángel Sotillo. 26-41. Madrid: Los Libros de la Catarata/IUDC-UCM.

Minoiu, Camelia, and Sanjay G. Reddy. 2010. "Developing Aid and Economic Growth: A Positive Long-Run Relation." The Quarterly Review of Economics and Finance 50 (1): 27-39. https://doi.org/10.1016/i.qref.2009.10.004

Moss, Todd J., Gunilla Pettersson, and Nicolas Gelander Van De Walle. 2006. “An AidInstitutions Paradox? A Review Essay On Aid Dependency And State Building In Sub-Sahara Africa." Center for Global Development Working Paper 74: 1-28. http://dx.doi.org/10.2139/ssrn.860826

Moyo, Dambisa. 2011. Cuando la Ayuda es el Problema: Hay Otro Camino para Africa. Translated by E. Pipino. Madrid: Gota a Gota Ediciones.

Nussbaum, Martha C. 2015. “The Central Capabilities.” In Antología del Desarrollo, edited by José Ángel Sotillo, 281-298. Madrid: Los Libros de la Catarata/IUDC-UCM.

Organisation for Economic Co-operation and Development (OECD). 2018. Private Philanthropy for Development, The Development Dimension. Paris: OECD Publishing. https://doi.org/10.1787/9789264085190-en

Organisation for Economic Co-operation and Development (OECD). 2019a. "Detailed Aid Statistics: ODA Official Development Assistance: Disbursements." https://www.oecdilibrary.org/development/data/oecd-international-development-statistics/oda-officialdevelopment-assistance-disbursements data-00069-en

Organisation for Economic Co-operation and Development (OECD). 2019b. "Total Flows by Donor https://stats.oecd.org/viewhtml.aspx?datasetcode=TABLE1\&lang=en\#

Oxfam. 2019. "Public Good or Private Wealth?." Oxfam Briefing Paper. Oxford: Oxfam GB. https://s3.amazonaws.com/oxfam-us/www/static/media/files/bp-public-good-or-privatewealth-210119-en.pdf

Oxfam Intermón. 2015. "La Ilusión Fiscal: Demasiadas Sombras en la Fiscalidad de las Grandes Empresas." Informe de Oxfam Intermón 36. http:/ / www.pensamientocritico.org/oxfam0315.pdf

Perroulaz, G., Claudie Fioroni, and Gilles Carbonnier. 2010. "Trends and issues in international development cooperation." International Development Policy/Revue internationale de politique de développement 1. https://doi.org/10.4000/poldev.142

Petras, James. 1998. “Intelectuales: Una Crítica Marxista de los Post-Marxistas.” In Los Retos de la Globalización. Ensayo en Homenaje a Theotonio Dos Santos, edited by Francisco López Segrera. 118. Caracas: UNESCO. http://biblioteca.clacso.edu.ar/ar/libros/unesco/petras.rtf 
Programa de las Naciones Unidas para el Desarrollo (PNUD). 2011. Sostenibilidad y Equidad: Un Mejor Futuro para Todos, Informe sobre Desarrollo Humano 2011. New York, NY: United Nations Development Programme. https://www.undp.org/content/undp/es/home/librarypage/hdr/human developmentrep ort2011.html

Quijano, Aníbal. 2001. “Colonialidad del Poder, Globalización y Democracia.” Utopias 188: $97-$ 123.

Rajan, Raghuram G., and Arvind Subramanian. 2008. "Aid and Growth: Why Does the CrossCountry Evidence Really Show?." Review of Economics and Statistics 90 (4): 643-665. https://doi.org/10.1162/rest.90.4.643

Rist, Gilbert. 2002. El Desarrollo: Historia de una Creencia Occidental. Madrid: Los Libros de la Catarata/IUDC-UCM.

Rodríguez, Dylan. 2017. "The Political Logic of the Non-Profit Industrial Complex." In The Revolution will not be Funded: beyond the Non-Profit Industrial Complex, edited by INCITE!, 21-40. Durham, NC: Duke University Press. https://doi.org/10.1215/9780822373001-002

Sachs, Jeffrey D. 2015. La Era del Desarrollo Sostenible: Nuestro Futuro Está en Juego: Incorporemos el Desarrollo Sostenible a la Agenda Política Mundial. Translated by R. V. Vernis. Bilbao: Deusto.

Sogge, David. 2004. Dar y Tomar: ¿Qué Sucede con la Ayuda Internacional?. Translated by A. Ruiz Mirazo and L. López. Barcelona: Icaria/Antrazyt.

Sogge, David. 2017. "Foreign Aid: Inconvenient Truths." Sinergias - diálogos educativos para a transformação social 5: 29-39. https://bit.ly/2YyVga6

Sotillo, J. Á. 2011. El Sistema de cooperación para el desarrollo. Actores, formas y procesos. Madrid: Los Libros de La Catarata.

Truman, H. S. 2015. “Truman's Inaugural Address.” In Antología del Desarrollo, edited by José Ángel, Sotillo, 64-69. Madrid: Ediciones Los Libros de la Catarata/IUDC-UCM.

United Nations (UN). 1997. Resolution Adopted by the General Assembly: A/RES/51/240 Agenda for Development,

October

15.

https://www.un.org/en/ga/search/view doc.asp?symbol=A/RES/51/240

United Nations (UN). 2015a. Resolution Adopted by the General Assembly: A/RES/69/313 Addis Ababa Action Agenda of the Third International Conference on Financing for Development, July 27. https://undocs.org/A/RES/69/313

United Nations (UN). 2015b. Resolution Adopted by the General Assembly: A/RES/70/1. Transforming our World: The 2030 Agenda for Sustainable Development, September 25. https://undocs.org/A/RES/70/1 (27 August 2019).

Wallerstein, Immanuel. 2000. “Oliver C. Cox as World-Systems Analyst.” Race and Ethnic Relations 11: 173-183. https://bit.ly/31nYC1k (25 June 2020) 
Wallerstein, Immanuel. 2012. El Capitalismo Histórico, 2nd ed. Translated by P. López Máñez. Madrid: Siglo XXI Editores.

WWF. 2018. "Living Planet Report - 2018: Aiming Higher." Report by M. Grooten and R.E.A. Almond (Eds). WWF: Gland, Switzerland. Available at: https://www.footprintnetwork.org/content/uploads/2018/10/LPR-2018-full-report.pdf

Žižek, Slavoj. 2003. "Introducción. El Espectro de la Ideología.” In Ideología, un mapa de la cuestión, edited by Slavoj Žižek. 7-43. Buenos Aires: Fondo de Cultura Económica. 